\title{
The role of microhabitat in predation on females with alternative dorsal patterns in a small Costa Rican anole (Squamata: Dactyloidae)
}

\author{
Evi A.D. Paemelaere ${ }^{1}$, Craig Guyer ${ }^{1} \&$ F. Stephen Dobson ${ }^{1,2}$ \\ 1. Department of Biological Sciences, 331 Funchess Hall, Auburn University, Auburn, AL 36849, USA; \\ paemeev@auburn.edu, guyercr@auburn.edu \\ 2. Centre d'Ecologie Fonctionnelle et Evolutive, UMR CNRS 5175, 1919 route de Mende, 34293 Montpellier Cedex 5, \\ France; fsdobson@msn.com
}

\author{
Received 12-IV-2012. Corrected 20-IX-2012. Accepted 22-X-2012.
}

\begin{abstract}
Papel del microhábitat en la depredación de hembras con patrones dorsales alternativos en una pequeña lagartija de Costa Rica (Squamata: Dactyloidae). Predation is one of the major selective agents influencing evolution of color patterns. Cryptic color patterns decrease detection probability by predators, but their concealing function depends on the background against which patterns are seen; therefore, habitat use and color patterns are tightly linked. In many anole species, females exhibit variation in dorsal color patterns; the drab and perhaps cryptic colors of the patterns suggest a predator avoidance function behind this polymorphism. We tested whether these different color patterns experience different predation rates depending on their microhabitat. We expected each pattern to form at least one optimal combination with a typically used micro-habitat that would result in lower predation compared to other morphs in the same micro-habitat. We tested this hypothesis for anoles at La Selva, Costa Rica, using clay models resembling a common species at this site: Norops humilis. The first experiment tested for variation in predation on various substrates. We included leaf litter, live leaves, and two size classes of woody stems, using 44 models for each pattern substrate combination. A second experiment tested effects of perch height $(10$ and $60 \mathrm{~cm})$ and diameter $(<2 \mathrm{~cm}$ and $>5 \mathrm{~cm})$, with 50 models for each pattern perch combination. We found differences in predation rates between the morphs depending on their micro-habitat. Specifically, the striped morph had a significant advantage over the others on green leaves. In the second experiment, striped morphs showed significantly lower predation on low than on high perches, irrespective of perch diameter. Reticulated models had an advantage over other morphs on thin stems for the first experiment, where models were placed about $60 \mathrm{~cm}$ high. Diameter did not have a significant effect on predation for reticulated morphs when height classes were combined. Dotted models did not experience an advantage over the other morphs in any of the treatments. In leaf litter and on thick perches no morph had any advantage over another, and leaf litter predation rates were generally low. These results support a role for predation in maintaining multiple female morphs within small Costa Rican anoles, such as N. humilis. Rev. Biol. Trop. 61 (2): 887-895. Epub 2013 June 01.
\end{abstract}

Key words: female polymorphism, Norops humilis, selection, predation, La Selva Biological Station, habitat use.

In animals, dorsal color patterns are often associated with protection from predation. Flashing coloration in prey species often functions as a warning signal for the predator, while drab color generally decreases visibility (Poulton 1890, Cott 1940, Edmunds 1974). Perception of color patterns, however, depends on the background that the animal is seen against (Endler 1978, Ruxton et al. 2004, Bond 2007), so that visibility is not inherent to a color pattern. Reduced visibility to predators (camouflage) can actually be obtained through color patterns that fail to stand out from the background (crypsis) or patterns that deflect the predator's vision from the contours of its prey. In the latter case the colors need not be similar to the background (Cott 1940, Endler 1978, Merilaita \& Lind 2005, Cuthill et al. 2007). A 
camouflaging color pattern can serve a generalist role, forming a compromise by providing camouflage against a variety of backgrounds, but not maximizing camouflage for each background separately (Merilaita et al. 1999, Merilaita et al. 2001). Alternatively, a pattern can be specialized for maximum concealment for a specific micro-habitat element and individuals may select different microhabitats within the heterogeneous environment, so that a variety of color patterns can be maintained within a population (Edmunds 1974, Endler 1978, Endler 1984, Hedrick 1986). In the latter case, predation in heterogeneous environments may result in color polymorphic populations (Ford 1945, Cain \& Sheppard 1954).

Anoles (Squamata: Dactyloidae) are known to vary in dorsal patterns within populations (e.g. Fitch 1975, Schoener \& Schoener 1976). Moreover, these pattern variations are primarily limited to females, and the same patterns re-occur in many species of anoles throughout their range (Savage 2002, Paemelaere et al. 2011a). These patterns vary in shape and do not appear to differ in color. Common female-only morphs or gynomorphs are the cream-colored vertebral striped and reticulated patterns. The variety of patterns may also include a male-like or andromorph pattern, which differs among species. The color pattern of these anoles consists of varieties of brown and green, suggesting that these patterns help reduce visibility to predators (Collette 1961, Fitch 1975, Macedonia 2001), but the maintenance of this polymorphism has rarely been studied.

In Norops sagrei (Duméril \& Bibron 1837) frequency dependent selection appears to play a role in the maintenance of three female morphs (Calsbeek et al. 2010), but for $N$. humilis (Peters 1863), no support was found for this mechanism (Paemelaere et al. 2011b). A comparative study found that female polymorphism in anoles is associated with perch use (Paemelaere 2010). Previous studies indicated that female morphs select different perches. In particular, striped females of $N$. sagrei appear to select thinner perches (Schoener \& Schoener
1976), while in $N$. polylepis (Peters 1874) striped females select higher perches (Steffen 2010). Both studies tested the hypothesis that dorsal pattern polymorphism in anoles is maintained through differential concealment among alternative morphs that select different backgrounds. Although perch use appears to differ among female morphs, no study has addressed the effect of predation on different morphs.

Methods have been developed to quantify how easily an individual is detected by a predator, depending on the background the individual is seen against (Endler 1990, Endler \& Mielke 2005). While these techniques allow for relatively easy assessment of background matching for color polymorphism, such techniques have not been well developed for pattern polymorphism (Endler \& Mielke 2005). Clay models have gained popularity to assess the interactions between predator and prey because predation is difficult to study under natural circumstances (Brodie 1993, Bittner 2003, Howe et al. 2009, Noonan \& Comeault 2009, Steffen 2009). The advantage of clay models is that individual variation, such as size and behavior, can be removed. Under the hypothesis of background matching by morphs, we expected to find different predation rates under a variety of pattern-background combinations. Specifically, we expected each morph to match at least one background for which predation of this morph was lower than for other morphs.

\section{MATERIALS AND METHODS}

We performed two experiments at the $\mathrm{La}$ Selva Biological Station, Costa Rica (10²6’ N

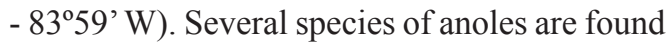
at La Selva that are polymorphic in female dorsal patterns. The most common polymorphic species are Norops humilis, $N$. limifrons and $N$. capito (Guyer \& Donnelly 2004). N. humilis measures up to $45 \mathrm{~mm}$ snout-vent length (SVL), and perches low on trunks and in the leaf litter (Fitch 1975, Talbot 1979). N. limifrons perches somewhat higher and females grow to $43 \mathrm{~mm}$ SVL. The larger $N$. capito measures up to $93 \mathrm{~mm}$ SVL and perches on tree trunks 
at heights similar to N. limifrons (Fitch 1973, Fitch 1975, Talbot 1979). Predators of these anoles include spiders, birds, snakes, lizards and arthropods (Guyer 1988). Females of the polymorphic anoles at La Selva can have one of three dorsal patterns: a male-like pattern, a reticulated pattern or a vertebral stripe that may vary from cream to brown depending on weather conditions (J.E. Steffen, pers. comm.). The male-like pattern consists of vertebral dots (sometimes no dots present) in N. humilis and $N$. limifrons. In $N$. capito, the entire dorsum has a lichenous pattern.

We exposed clay models to free-ranging predators. The clay lizards represented the reticulated and striped gynomorph and dotted andromorph modeled after $N$. humilis (Fig. 1). Each model measured 50mm SVL and the tails measured $70 \mathrm{~mm}$. Models were made from non-hardening, odorless, non-toxic modeling clay (VanAken ${ }^{\mathrm{TM}}$ ), and constructed with a self-made mould (SELVA brand silicone rubber HB). The soft clay allowed observation of impressions resulting from predator attacks

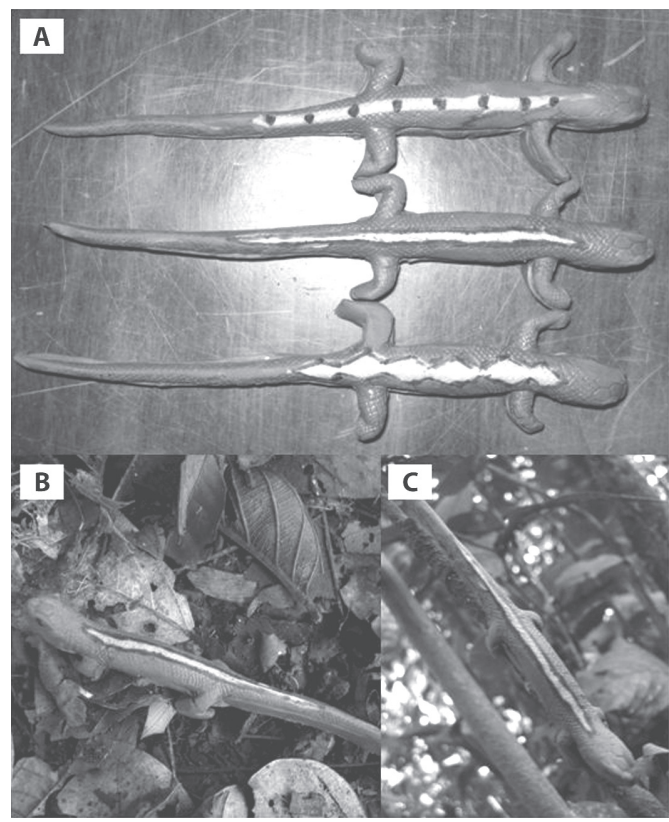

Fig. 1. Clay models. (A) From top to bottom: dotted, striped and reticulated pattern, (B) Model on leaf litter, (C) Model attached to perch.
(Brodie 1993). The brown base color for the models was chosen to match $N$. humilis by human eye. The clay did not reflect UV, but UV radiation from the body has not been found in other species of anoles and was therefore not expected in $N$. humilis (Macedonia et al. 2003). The outline of the reticulated pattern and the vertebral stripe were drawn with a black permanent marker. The same marker was also used for the vertebral dots and for the eyes. All models on perches were placed head down and kept in place by a metal wire through the ventral midsection.

Perch substrate: The first study took place in June, 2007. Clay models were placed on four different substrates that represented habitat elements where the polymorphic anoles were seen: leaf litter, green (live) leaves, stems less than $2 \mathrm{~cm}$ diameter and stems more than $5 \mathrm{~cm}$ diameter. All stems were woody, to avoid effects of green versus brown stems. On live leaves and stems, models were placed as close to $60 \mathrm{~cm}$ high as possible, because this is the average perch height of adult $N$. humilis (Talbot 1979). Each pattern-substrate combination received 44 models, for a total of 528. 11 study plots each contained four replications of each of 12 possible combinations of dorsal pattern and substrate. A random number was assigned to every combination using 'sample(48)' in $\mathrm{R}$ Version 2.8.1 ( $\mathrm{R}$ Development Core Team 2008), and used as the order in which the combinations were placed within the plot. Models were placed in six rows. The minimum distance between models was two meters, but this distance increased if the pre-determined perch type was located at a slightly greater distance. Models were checked every third day. Models with predation were removed from the plot and damaged models were repaired by smoothing the surface. Because damage from ants increased over time, all models were collected after 12 days.

Perch diameter and height: In July 2007, a second study investigated the effect of perch height and diameter on predation. Models were 
placed vertically on stems of different diameters and at different heights. The diameter of the stem was lower than $2 \mathrm{~cm}$ or thicker than $5 \mathrm{~cm}$. Models were placed at $10 \mathrm{~cm}$ or $60 \mathrm{~cm}$ height from the forest floor. Combinations were randomized and placement depended on the availability of perches as described above. For each of 12 combinations of pattern, diameter and height, 50 models were prepared for a total of 600 models. They were placed in plots as described above and left for four days before collecting all of the models and checking them for signs of predation.

Both experiments were carried out in disturbed forest (abandoned plantations, secondary growth). All three common polymorphic species were encountered in this type of habitat. Plots were separated by at least $100 \mathrm{~m}$. Upon collecting the models, they were placed in Ziploc bags and transported to the lab, where predation marks were recorded. In both experiments, predation rates per pattern per background were summed over the full duration of the experiment. Only V or U-shaped imprints and small symmetric slits and punctures were scored as predation (Brodie 1993, Saporito et al. 2007, Steffen 2009) (Fig. 2). Ant damage was not scored as predation. When multiple predator marks were seen on one individual, a single predation event was scored. Occasionally tails were found to have fallen off of the model onto the ground. Marks on these tails
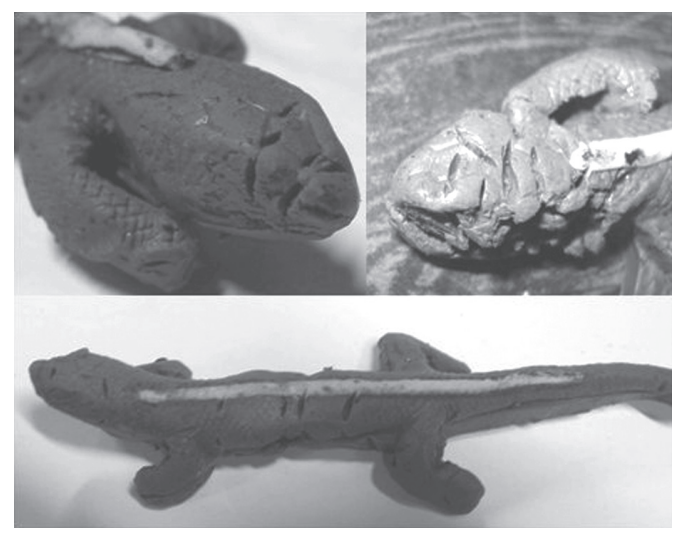

Fig. 2. Bite marks categorized as predation. were not included in the analysis. Models that were not retrieved were considered lost. Analyses were run with and without scoring the lost models as predation events. In addition, analyses were ran with serially attacked models removed, because attacks on neighboring models could result from easier detection after one of the models had been approached.

In the first experiment, absence or presence of predation on the model was compared for the different pattern-background combinations. We used a randomization test of independence with 5000 iterations partitioned per background (McDonald 2009). The strength of the association was reported as Cramér's phi $\left(\varphi_{\mathrm{c}}\right)$, which ranges between 0 and 1 , but 0.5 would be considered a strong association, 0.3 medium and 0.1 weak. In the second experiment, this test was also used to determine differences in predation at differing perch heights and on differing perch diameters for each morph. The same randomization test was also used for each experiment to determine differences in predation rate on morphs, independent of the perch they were on. All analyses were completed with proc freq in SAS/STAT ${ }^{\circledR}$ software, Version 9.1.3 for SAS System for Windows.

\section{RESULTS}

Perch substrate: Of 515 retrieved models, $111(21 \%)$ showed signs of predation. Overall, predation was highest on dotted (andromorph) models, moderate for reticulated gynomorphs, and lowest for striped gynomorphs (Dotted: $29.8 \%$, Reticulated: $19.5 \%$, Striped: $15.6 \%$, $\left.\mathrm{X}^{2}{ }_{(2, \mathrm{~N}=515)}=9.06, \mathrm{p}=0.01, \varphi_{\mathrm{c}}=0.13\right)$. For models placed on live leaves, the number of predation events differed significantly between morphs; striped morphs experienced less predation than expected, while the opposite was true for both other morphs $\left(\mathrm{X}_{(2, \mathrm{~N}=129)}^{2}=6.45, \mathrm{p}=0.04\right.$, $\varphi_{c}=0.22$; Fig. 3). On stems with a diameter less than two centimeters, the reticulated model had a lower attack rate and the dotted morph a much higher attack rate than expected $\left(\mathrm{X}^{2}{ }_{(2}\right.$, $\left.\mathrm{N}=131)=8.30, \mathrm{p}=0.02, \varphi_{\mathrm{c}}=0.24\right)$. Predation in leaf litter was generally very low and did 
Leaf Litter

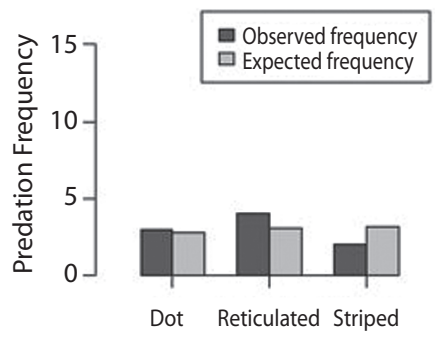

Stem - Diameter $<2 \mathrm{~cm}$

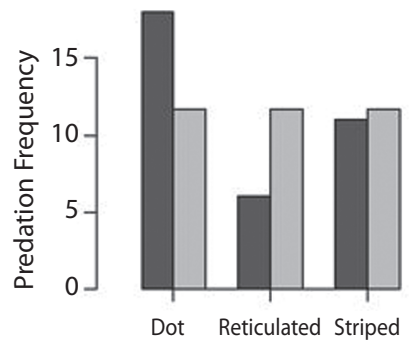

Green Leaf*

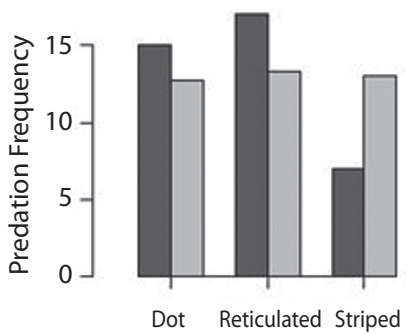

Stem - Diameter $<5 \mathrm{~cm}$

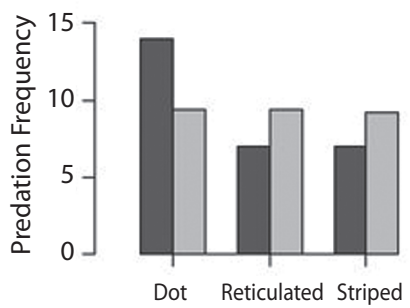

Fig. 3. Predation frequencies for pattern-background combinations from experiment 1. Each background is represented separately. Significant difference at 0.05 level are indicated with a star $\left(^{*}\right)$. Both observed and expected frequencies are shown to demonstrate how the patterns differed.

not significantly differ among morphs $\left(\mathrm{X}^{2}{ }_{(2}\right.$ $\left.\mathrm{N}=123)=0.81, \mathrm{p}=0.67, \varphi_{\mathrm{c}}=0.08\right)$. Similarly, no significant difference was found in predator attacks on models placed on stems greater than five centimeters in diameter $\left(\mathrm{X}^{2}{ }_{(2, \mathrm{~N}=132)}=4.26\right.$, $\left.\mathrm{p}=0.12, \varphi_{\mathrm{c}}=0.18\right)$. When repeating the analysis with lost models scored as predation, results were virtually unchanged (not shown). Removing serially attacked models resulted in similar patterns of predation rates, but low sample size resulting in insignificant differences (not shown).

Perch diameter and height: Of 600 models, 593 were retrieved and, of these, $6.7 \%$ showed signs of predation. No significant difference in predation was found for morphs placed at perches less than two or more than five centimeters diameter (Dotted: $\mathrm{X}_{(1, \mathrm{~N}=196)}=0.88, \mathrm{p}=0.35, \varphi_{\mathrm{c}}=-0.07$; Reticulated: $\mathrm{X}_{(1, \mathrm{~N}=198)}=0.07, \mathrm{p}=0.79, \varphi_{\mathrm{c}}=0.02$; Striped:
$\mathrm{X}_{(1, \mathrm{~N}=199)}^{2}=0.00, \mathrm{p}=0.95, \varphi_{\mathrm{c}}=0.00$; Fig. 4). When comparing predation between low and high perches, dotted and reticulated morphs did not significantly differ in predation (Dotted: $\mathrm{X}_{(1, \mathrm{~N}=196)}=0.10, \mathrm{p}=0.76, \varphi_{\mathrm{c}}=-0.02$; Reticulated $\left(\mathrm{X}_{(1, \mathrm{~N}=198)}^{2}=1.73, \mathrm{p}=0.19, \varphi_{\mathrm{c}}=-0.09\right)$. Striped morphs, on the other hand, were predated significantly less on the lower perches $\left(\mathrm{X}^{2}{ }_{(1}\right.$, $\left.\mathrm{N}=199)=4.95, \mathrm{p}<0.03, \varphi_{\mathrm{c}}=-0.15\right)$. In our study, predation did not differ between female pattern morphs $\left(\mathrm{X}_{(1, \mathrm{~N}=593)}^{2}=0.66, \mathrm{p}=0.72\right)$. Repeating the analysis with lost models scored as predation did not change the conclusions.

\section{DISCUSSION}

The microhabitat hypothesis for maintaining female polymorphism predicts that predation differs based on pattern-background combinations. Hence, survival would be highest for females selecting the background that 

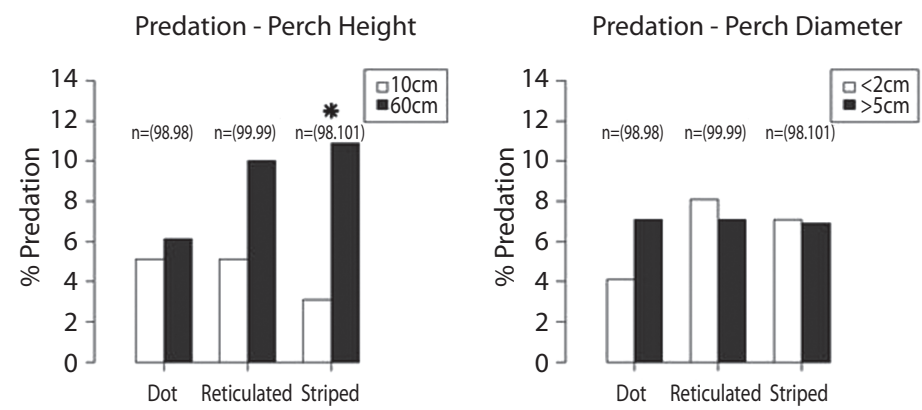

Fig. 4. Predation for different heights and diameters of woody stems from experiment 2. Significance is indicated by a star (*). Sample sizes are given above the bars.

provides the best concealment for their pattern. The prolonged survival and consequent higher lifetime reproductive output of these females could be sufficient for polymorphism to be maintained. Our first experiment showed that clay models representing female morphs of common anoles at La Selva differ in the rate of predator attacks, depending on the substrate they were placed on. We also found a higher overall predation rate on dotted morphs compared to the other two, but this difference was not seen in the second experiment. In the second experiment, striped morphs exhibited lower predation rates on relatively low perches, with a non-significant qualitative trend in this direction by reticulated morphs.

The difference between the first and second experiment could be due to differences in the predation rates. Predation in the first study was high compared to the typical predation rate of $5-10 \%$ on clay models (Bittner 2003, Husak et al. 2006). This rate was found in studies leaving models in the field between four and seven days and thus the difference in predation rate may be due to the relatively long time period (12 days) during which models in the first experiment were left in the field. Indeed, predation rate per day was $1.75 \%$, so that four days would result in a $7 \%$ predation rate. The second study, in which models were left out for four days, predation rate was $6.7 \%$, and thus consistent with predation rates generally seen in clay model studies.
The first study showed that the reticulated morph had a significant advantage over striped and dotted morphs on thin stems, at least when placed at $60 \mathrm{~cm}$ high (where the second experiment showed that $\%$ predation was relatively high). When low $(10 \mathrm{~cm})$ and high $(60 \mathrm{~cm})$ heights were combined in the second study, no significant effect of diameter was seen on predation rates for the reticulated morph, though there was a nearly doubled rate of predation at the greater height. The striped morph had lower predation than expected on all substrates, but it had particular advantage over the other two on green leaves. Although the brown coloration of all morphs stands out against the green background of these leaves, the stripe may function as a disruptive pattern (Cott 1940), rendering it more effective on backgrounds that are in strong contrast with the brown body color (Stevens \& Cuthill 2006). For stems, the typical, elevated perch for $N$. humilis, striped morphs were found to experience significantly less predation on low stems, compared to higher perches. Predation on the dotted morph was generally higher than expected. The higher predation rate on the dotted morph in the first study suggests that this andromorph pattern may be the least concealing.

Females of $N$. humilis spend much time on the leaf litter and predation was low in the leaf litter for all morphs. The lower predation in the leaf litter could be because the different morphs are equally camouflaged in this diverse background. Alternatively, predation on the 
leaf litter could be lower due to greater activity of predators at greater heights. Anoles have been shown to experience lower predation at lower perch heights (Steffen 2009). This was confirmed by results of the second experiment, where all morphs experienced less predation on low versus high perches, although this was only significant for the striped morph. Lower predation on females in the leaf litter could result in relaxed selection on morphs. Because not all species of female polymorphic anoles frequently roam the leaf litter, this could not explain the occurrence of multiple morphs in those species.

With only the reticulated and striped morph showing a predation advantage at select perches, and considering the higher overall predation rate on dotted andromorphs in the first experiment, results suggest that the gynomorph patterns may have evolved in response to predation, while the dotted morph may not have. Nevertheless, the dotted morph represents the highest frequency of females, and it is the typical male pattern in N. humilis at $\mathrm{La}$ Selva. The high frequency of dotted females could, perhaps, result from its presence in males combined with a dominant allele coding for vertebral dots. In female polymorphic damselflies, the pattern seen in males as well as females was found to be coded by a dominant autosomal allele (Andres \& Cordero 1999). Alternatively, dotted females could benefit in other ways; for example a benefit might accrue through increased male attention based on their higher frequency in the population (Cordero 1992, Van Gossum et al. 2001).

If gynomorph patterns have evolved in response to predation, as suggested by our results, then it is not surprising that males have not evolved these pattern variations. Their different morphology, behavior and ecology compared to females are expected to reduce the potential benefit of cryptic patterns. First, males are more vigilant, while females are more focused on food acquisition and perhaps less mobile due to continuous presence of eggs (Bauwens \& Thoen 1981, but see Schwarzkopf \& Shine 1992, Lee et al. 1996, Lailvaux et al.
2003). Males may also use dewlap displays to deter predators (Leal \& Rodriguez-Robles 1997). Therefore, to avoid predation females may rely more on camouflage than males. Furthermore, crypsis is affected by movement (Stevens 2007). Predation benefits found in our study apply to motionless individuals. The advantage may disappear in motion and thus be most effective for the less mobile females. Next, the gynomorph patterns may not have the same concealing effect on males as on females due to differences in body shape between slender males and gravid females as seen in Lampropholis delicate (Forsman \& Shine 1995, Merilaita \& Lind 2005). Finally, colorful dewlap displays by males also defeat the purpose of cryptic patterns (Fleishman 1991).

Overall, our results supported the hypothesis of differential predation on morphs based on the background against which they were seen. The second prediction of the microhabitat hypothesis is that individuals select the background that provides the best concealment for their pattern. Future research should test whether these anoles are indeed selecting the perches where predation is lowest for their dorsal pattern.

\section{ACKNOWLEDGMENTS}

We are grateful to $\mathrm{M}$. Wooten and B. Zinner for comments on earlier versions of the manuscript. L. Pastorello provided assistance with statistical procedures. M. Paemelaere helped with the design of the mold and construction of models, and A. Liner and R. Conway assisted in the field. We thank R. Saporito for helpful tips on clay model experiments. We also owe our gratitude to the staff of the La Selva Biological station. This research was funded by the Organization for Tropical Studies and the Auburn University Graduate School. This research was approved by IACUC, permit number 2007-1177, and by the Costa Rican Ministry of Environment and Energy (MINAE), permit number 01521. 


\section{RESUMEN}

En los animales, los patrones dorsales de coloración a menudo se asocian con la protección contra la depredación. Con el fin de analizar el papel que tienen los micro-hábitat en la depredación de lagartijas hembras que presentan variaciones en los patrones de coloración dorsal (colores grises, crípticos), se realizó en la Estación Biológica La Selva, Costa Rica un estudio con el objetivo de comprobar si los patrones de diferentes colores provocan cambios en las tasas de depredación en función de a su micro-hábitat; se esperaba que cada patrón formara una combinación óptima utilizando el micro-habitat y que permitiera de esta manera reducir los niveles de depredación. Para evidenciar esta hipótesis se utilizaron modelos de arcilla que asemejan a la especie Norops humilis propia del lugar. Se realizaron dos estudios, el primero analizó modelos colocados en cuatro sustratos diferentes: hojarasca, hojas vivas y dos clases de tamaño de tallos leñosos, los cuales representaban cada hábitat donde es posible observar esta especie. Un segundo experimento estudió el efecto de la altura y el diámetro de la percha en la depredación, para ello se colocaron los modelos sobre tallos de diferentes alturas y diámetros. Fue posible observar en el primer experimento que el morfo rayado tuvo una ventaja significativa sobre los demás morfos en las hojas verdes y que los modelos reticulados tuvieron una ventaja sobre otros morfos en tallos delgados. El segundo estudio mostró que los morfos rayados tienen una tasa de depredación baja en perchas altas, independientemente del diámetro de la percha. Fue posible comprobar que los morfos punteados no experimentaron ventaja sobre otros morfos en ninguno de los dos estudios.

Palabras clave: poliformismo, Norops humilis, selección, depredación, Estación Biológica La Selva, hábitat.

\section{REFERENCES}

Andres, J.A. \& A. Cordero. 1999. The inheritance of female colour morphs in the damselfly Ceriagrion tenellum (Odonata, Coenagrionidae). Heredity 82: 328-335.

Bauwens, D. \& C. Thoen. 1981. Escape tactics and vulnerability to predation associated with reproduction in the lizard Lacerta vivipara. J. Anim. Ecol. 50: 733-743.

Bittner, T.D. 2003. Polymorphic clay models of Thamnophis sirtalis suggest patterns of avian predation. Ohio J. Sci. 103: 62-66.

Bond, A.B. 2007. The evolution of color polymorphism: Crypticity searching images, and apostatic selection. Annu. Rev. Ecol. Evol. Sys. 38: 489-514.

Brodie, E.D. 1993. Differential avoidance of coral snake banded patterns by free-ranging avian predators in Costa-Rica. Evolution 47: 227-235.
Cain, A.J. \& P.M. Sheppard. 1954. The theory of adaptive polymorphism. Am. Nat. 88: 321-326.

Calsbeek, R., L. Bonvini \& R.M. Cox. 2010. Geographic variation, frequency-dependent selection, and the maintenance of a female-limited polymorphism. Evolution 64: 116-125.

Collette, B.B. 1961. Correlations between ecology and morphology in anoline lizards from Havana, Cuba and southern Florida. Bull. Mus. Comp. Zool. 125: 137-162.

Cordero, A. 1992. Density-dependent mating success and color polymorphism in females of the damselfly Ischnura graellsii (Odonata, Coenagrionidae). J. Anim. Ecol. 61: 769-780.

Cott, H.B. 1940. Adaptive coloration in animals. Methuen, London, United Kingdom.

Cuthill, I.C., T.S. Troscianko, A. Kibblewhite, O. King \& M. Stevens. 2007. Edge enhancement in disruptive camouflage. Perception 36: 1399.

Duméril, A.M.C. \& G. Bibron. 1837. Erpétologie générale ou histoire naturelle complete des reptiles. Vol. 4., Paris, France.

Edmunds, M. 1974. Defence in animals. Longman, Harlow, United Kingdom.

Endler, J.A. 1978. A predator's view of animal color patterns. Evol. Biol. 11: 319-364.

Endler, J.A. 1984. Progressive Background in Moths, and a Quantitative Measure of Crypsis. Biol. J. Linn. Soc. 22: $187-231$.

Endler, J.A. 1990. On the Measurement and Classification of Color in Studies of Animal Color Patterns. Biol. J. Linn. Soc. 41: 315-352.

Endler, J.A. \& P.W. Mielke. 2005. Comparing entire colour patterns as birds see them. Biol. J. Linn. Soc. 86: 405-431.

Fitch, H.S. 1973. A field study of Costa Rican lizards. Univ. Kansas Sci. Bull. 50: 39-126.

Fitch, H.S. 1975. Sympatry and interrelationships in Costa Rican anoles. Occ. Pap. Mus. Nat. Hist. Univ. Kansas 40: $1-60$.

Fleishman, L.J. 1991. Design features of the displays of anoline lizards, p. 33-48 In J.B. Losos \& G.C. Mayer (eds.). Anolis Newsletter IV. National Museum of Natural History, Smithsonian Institution, Washington, D.C., USA.

Ford, E.B. 1945. Polymorphism. Biol. Rev. Camb. Philos. Soc. 20: 73-88.

Forsman, A. \& R. Shine. 1995. The adaptive significance of color pattern polymorphism in the Australian Scincid Lizard Lampropholis delicata. Biol. J. Linn. Soc. 55: 273-291.

Guyer, C. 1988. Food supplementation in a tropical mainland anole, Norops humilis - Demographic Effects. Ecology 69: 350-361. 
Guyer, C. \& M.A. Donnelly. 2004. Amphibians and reptiles of La Selva, Costa Rica, and the Caribbean Slope. University of California, Berkeley, California.

Hedrick, P.W. 1986. Genetic-polymorphism in heterogeneous environments - a decade Later. Annu. Rev. Ecol. Syst. 17: 535-566.

Howe, A., G.L. Lovei \& G. Nachman. 2009. Dummy caterpillars as a simple method to assess predation rates on invertebrates in a tropical agroecosystem. Entomol. Exp. Appl. 131: 325-329.

Husak, J.F., J.M. Macedonia, S.F. Fox \& R.C. Sauceda. 2006. Predation cost of conspicuous male coloration in collared lizards (Crotaphytus collaris): An experimental test using clay-covered model lizards. Ethology 112: 572-580.

Lailvaux, S.P., G.J. Alexander \& M.J. Whiting. 2003 Sex-based differences and similarities in locomotor performance, thermal preferences, and escape behaviour in the lizard Platysaurus intermedius wilhelmi. Physiol. Biochem. Zool. 76: 511-521.

Leal, M. \& J.A. Rodriguez-Robles. 1997. Antipredator responses of the Puerto Rican giant anole, Anolis cuvieri (Squamata: Polychrotidae). Biotropica 29: 372-375.

Lee, S.J., M.S. Witter, I.C. Cuthill \& A.R. Goldsmith. 1996. Reduction in escape performance as a cost of reproduction in gravid starlings, Sturnus vulgaris. Proc. R. Soc. Lond. B. Biol. Sci. 263: 619-623.

Macedonia, J.M. 2001. Habitat light, colour variation, and ultraviolet reflectance in the Grand Cayman anole, Anolis conspersus. Biol. J. Linn. Soc. 73: 299-320.

Macedonia, J.M., A.C. Echternacht \& J.W. Walguarnery. 2003. Color variation, habitat light, and background contrast in Anolis carolinensis along a geographical transect in Florida. J. Herpetol. 37: 467-478.

McDonald, J.H. 2009. Handbook of Biological Statistics. Sparky, Baltimore, Maryland, USA.

Merilaita, S. \& J. Lind. 2005. Background-matching and disruptive coloration, and the evolution of cryptic coloration. Proc. R. Soc. Biol. Sci. Ser. B 272 : 665-670.

Merilaita, S., A. Lyytinen \& J. Mappes. 2001. Selection for cryptic coloration in a visually heterogeneous habitat. Proc. R. Soc. Lond. B. Biol. Sci. 268: 1925-1929.

Merilaita, S., J. Tuomi \& V. Jormalainen. 1999. Optimization of cryptic coloration in heterogeneous habitats. Biol. J. Linn. Soc. 67: 151-161.

Noonan, B.P. \& A.A. Comeault. 2009. The role of predator selection on polymorphic aposematic poison frogs. Biol. Lett. 5: 51-54.

Paemelaere, E.A.D. 2010. Evolution of female polymorphism in a Neotropical radiation of lizards. Biological Sciences. Auburn University, Auburn, Alabama, USA.

Paemelaere, E.A.D., C. Guyer \& F.S. Dobson. 2011a. A phylogenetic framework for the evolution of female polymorphism in anoles. Biol. J. Linn. Soc. 104: 303-317.

Paemelaere, E.A.D., C. Guyer \& F.S. Dobson. 2011b. Survival of alternative dorsal-pattern morphs in females of the anole Norops humilis. Herpetologica 67: 420-427.

Peters, W.C.H. 1863. Über einige neue Arten der Saurier-Gattung Anolis. Ber. Akad. Wiss. Berlin 1863: 135-149.

Peters, W.C.H. 1874. Über neue Saurier (Spæriodactylus, Anolis, Phrynosoma, Tropidolepisma, Lygosoma, Ophioscincus) aus Centralamerica, Mexico und Australien. Ber. Akad. Wiss. Berlin 1863: 738-747.

Poulton, E.B. 1890. The Colour of Animals: Their Meaning and Use. Kegan Paul, Trench, Trubner, London, United Kingdom.

R Development Core Team, T. 2008. R: A Language and Environment for Statistical Computing. . R Foundation for Statistical Computing, Vienna, Austria.

Ruxton, G.D., T.N. Sherratt \& R.C. Speed. 2004. Avoiding Attack: The Evolutionary Ecology of Crypsis, Warning Signals and Mimicry. Oxford University, Oxford, United Kingdom.

Saporito, R.A., R. Zuercher, M. Roberts, K.G. Gerow \& M.A. Donnelly. 2007. Experimental evidence for aposematism in the dendrobatid poison frog Oophaga pumilio. Copeia 1006-1011.

Savage, J.M. 2002. The Amphibians and Reptiles of Costa Rica: A Herpetofauna between Two Continents, between Two Seas. The University of Chicago, Chicago, Illinois, USA.

Schoener, T.W. \& A. Schoener. 1976. Ecological context of female pattern polymorphism in lizard Anolis sagrei. Evolution 30: 650-658.

Schwarzkopf, L. \& R. Shine. 1992. Costs of reproduction in lizards - escape tactics and susceptibility to predation. Beh. Ecol. Soc. 31: 17-25.

Steffen, J.E. 2009. Perch-height specific predation on tropical lizard clay models: implications for habitat selection in mainland neotropical lizards. Rev. Biol. Trop. 57: 859-864.

Steffen, J.E. 2010. Perch height differences among female Anolis polylepis exhibiting dorsal pattern polymorphism. Rept. Amph. Conserv. Nat. Hist. 17: 89-94.

Stevens, M. 2007. Predator perception and the interrelation between different forms of protective coloration. Proc. R. Soc. Biol. Sci. Ser. B 274: 1457-1464.

Stevens, M. \& I.C. Cuthill. 2006. Disruptive coloration, crypsis and edge detection in early visual processing. Proc. R. Soc. Biol. Sci. Ser. B 273: 2141-2147.

Talbot, J.J. 1979. Time budget, niche overlap, inter- and intraspecific aggression in Anolis humilis and Anolis limifrons in Costa Rica. Copeia 472-481.

Van Gossum, H., R. Stoks \& L. De Bruyn. 2001. Reversible frequency-dependent switches in male mate choice. Proc. R. Soc. Lond. B. Biol. Sci. 268: 83-85. 
